\title{
Inequality, Poverty and Education in the Post-Yugoslav Space: from immobility to inclusion? ${ }^{\text {I }}$
}

Paul Stubbs

Introduction

In this paper, I want to focus on education from a social justice perspective; a perspective that is all too often squeezed out by two other perspectives or frames. One, associated with the neoliberal phase of capitalism, addresses education in terms of preparation for the labour market, focusing on the supposed skills and competences required in the post-industrial, artificial intelligence-driven, societies of the future and, in particular, on the magic formula of STEM - science, technology, engineering and mathematics. The other, associated with what the Croatian sociologist Josip Županov (2002) referred to as desecularization (occurring alongside descientisation, retraditionalisation and repatriarchalisation), sees education as inculcating and ensuring the reproduction of national, cultural, religious, values, with schools as a place for prayer but not for sex education, apparently, and for a singular, and distorted, reading of national history. Although not the topic at hand here, I am particularly worried by the rise of a kind of authoritarian neoliberalism across the region and beyond that manages to combine the two frames perfectly well (Stubbs and Lendvai, 2019).

1 This paper is based on a keynote lecture delivered to the 4 th annual scientific conference on Research in Education and Training in Ljubljana, Slovenia on 18 September 2019. Thanks to Igor Žagar and Ana Mlekuž for their encouragement, and to Karin Doolan, Teo Matković, Saša Baucal and Slobodan Cvejić for comments on a previous draft and for guidance in searching for, and interpreting, the relevant literature. Responsibility for the text is mine alone, of course. 
The paper starts with a case study of media coverage following the President of Croatia's daughter gaining a place to study as an undergraduate at Harvard University. The next section looks historically at studies of education and mobility in socialist Yugoslavia. Section three turns to an overview of research on educational inequality in the post-Yugoslav space, surveying a literature that leaves us with more questions than answers. I then focus on my own research on child poverty and household coping strategies in Croatia before ending with some thoughts on whether another education - education otherwise - is possible, one that is not only or primarily about neoliberal skills or nationalist values, but which promotes equal opportunities, social mobility and social inclusion, borrowing, in particular, from the work of Pierre Bourdieu and Paolo Freire.

\section{The case of the president's daughter}

For three days in May 2019, the Croatian public became obsessed with the issue of education and mobility, following the acceptance of the daughter of President Kolinda Grabar-Kitarović for a fully funded place as an undergraduate at Harvard University. Once the media frenzy had died down, the debate on education and social mobility returned to normal; that is to say, it ceased to exist. Revisiting the media frenzy for the purposes of this paper, I was struck by how limited it was. What unfolded was a rather binary opposition between those who felt that Katarina Kitarović had obtained her place purely on merit, her mother proudly announcing she had scored in the top $1 \%$ of her SATs, and had been offered places by all four Ivy League colleges she had applied to; and those who felt that her acceptance was as much due to parental wealth, influence and connections/veze. A side debate occurred about whether studying abroad was a betrayal of Croatia or, as the Minister of Education Blaženka Divljak suggested, a good thing, whilst warning that »Croatia must ensure the conditions for returning and remaining for young educated people« (Trstenjak, 2019). The President's own statement noted her daughter's "wish to be free of the police officers who follow her twenty-four hours a day" and then joined in the debate, thus: "I have heard stories that she was accepted by Harvard because I am the President of Croatia, which has nothing to do with the truth because, as you know, the American education system takes no account of that." (Vojković, 2019)

The commentator Goran Vojković, on Index.hr, the very portal which carried many of the most critical articles, attacked the 'sick and pathetic' 
Croatian society for contributing to a climate where "verything can be forgiven except success «. Croatia should be proud, for Katarina's success is Croatia's success, a success that costs the rest of us nothing and stands in sharp contrast to other children of the rich and famous, who tend to have their lives more often paraded in the crna kronika section of newspapers (Vojković, 2019). Some news portals found others, from more humble backgrounds, who had also been educated in Harvard, or Princeton, or Cambridge, expounding what I like to term the Vlak $u$ snijegu meets Thatcherism maxim of "you can do anything if you put your mind to it" ("sve se može kad se hoće") (Plivelić, 2019). There were even "how to help your child get to Harvard' guides framed in terms of a sea change because, to quote one example, wit used to be thought that only the swotty kids of the rich could enroll, but now anyone can" (ibid.). We also learnt that the daughter of the former President of the Croatian Medical Chamber would be joining Katarina at Harvard (Dnevno, 2019).

Perhaps the most serious treatment of the case came from Nenad Jaric Dauenhauer (2019), also writing in Index.hr. He makes the link between the individual case and the question "how can the wealth and power of parents contribute to the academic success of their children?«. As the child of a diplomat, Katarina was educated, mainly at the expense of the Croatian taxpayer and, subsequently, NATO, in elite schools in Washington DC and Brussels. When her mother became President, she did her final year of schooling in the prestigious IB (International Baccalaureat) programme (a programme in English with a widely recognized 'modern curriculum') within the Mathematics High School in Zagreb, at a cost of some 3,000 Euro. Individual preparation for the SATs cost around 2,00o Euro and she also received individual mentoring in mathematics and in creative writing, the latter from a famous Croatian author, at an unknown cost.

Katarina was, clearly, appealing to Harvard, showing sporting prowess (she had been Croatian junior skating champion in 2016), showing compassion beyond her years (she had, apparently, written a book of short stories to help those of her classmates who were having suicidal thoughts) and had undoubtedly left a lasting impression on both faculty and students in the interview and discussion process that many have argued is the least transparent aspect of Harvard's selection process. As he also pointed out, $30 \%$ of Ivy League students have at least one parent who attended the same university (Kolinda did not) and the average annual parental income of Harvard students is some $\$ 170,000$. Looked at in terms of income quin- 
tiles, only $4.5 \%$ of students come from households with incomes in the bottom quintile and there are the same number of students from the top $1 \%$ of income earners as from the bottom $60 \%$. Of course, the issue is complicated here by transnational comparisons. Certainly, Kolinda's salary when an Assistant Secretary General of NATO was extremely high internationally. As a number of the articles point out, the stipend Katarina will receive from Harvard is twice her mother's monthly salary as President of Croatia, some net 25,000 HRK or 3,400 Euro. We should not worry too much about financial hardship in this case, however; recently, N1 reported that together with her husband Jakov, the President had savings amounting to $1.8 \mathrm{mil}$ lion kuna (240,00o Euro) and two properties with a total worth of $3.8 \mathrm{mil}$ lion kuna (o.5m. Euro) (N1 Info, 2019).

It is worth speculating on what Pierre Bourdieu would have made of the discussion, not least because his work makes a direct connection between diverse kinds of 'capital' and educational success. In Bourdieu's terms, it would be nonsense to ask if Katarina got her place on merit or through veze; or whether the material wealth of her parents made a difference or not. Bourdieu would elaborate on his concept of 'cultural capital', the intangible assets or dispositions, accumulated, or not, over time, in a relation of exchange with material wealth and correlated with attendance and success at the 'best' schools and universities (Bourdieu and Passeron, 1977). Cultural capital is the force that amplifies material inequalities, converting them, via academic success, into the reproduction of social stratification. Although there are no direct guarantees, Katarina's cultural capital was certainly high, with each and every aspect reinforcing and strengthening the others over time. What was perhaps most surprising was that, apart from comments about how bad Croatian universities were, there was little or no discussion of education and social mobility in Croatia itself.

\section{Education and social stratification in socialist Yugoslavia}

There have also been very few studies of education and social stratification in socialist Yugoslavia. Here, Kolinda Grabar-Kitarović is, also, not a great authority, in view of some of her repeated statements on the challenges of growing up near Rijeka between 1968 and 1986, going to Rijeka's gymnasium having rejected the place in a trade school offered by Šuvar's reforms and, in fourth grade of secondary school, becoming an exchange student in Los Alamos in the United States. Her recollections of the totalitarian system she lived under, "Behind the Iron Curtain" as she would have us be- 
lieve, include that one could not openly identify as 'Croat' (Tito did so frequently, however); there was only one sort of yoghurt in the shops, bread consumption was tightly controlled, hygienic products could not be obtained and one word critical of the regime and you would be sent to Goli Otok (Benačić, 2018).

The more I delve into aspects of the history of socialist Yugoslavia, the more I come to identify with the title of Darko Suvin's recent book, seeing Yugoslavia as a roller coaster of 'Splendour, Misery, and (Missed) Possibilities' (Suvin, 2016). I use the metaphor of a 'roller coaster' because it was far from a linear process of optimism leading, inexorably, to despair. Nevertheless, and here I borrow from the work of Karin Doolan and others (cf. Doolan et al, 2017), it is possible, albeit very crudely, to divide education and mobility in Yugoslavia into three conjunctures. The first, and one could argue whether this predates the break with Stalin and expulsion from the Cominform in 1948, was a period of rapid modernization and industrialization, including the fight against illiteracy and the massive expansion of higher education, both through universities and other third level institutions such as two- and four-year High Schools. Access to higher education was free and, at least theoretically, open to all; indeed, the children of peasants and the working-class were encouraged to stay on longer at school. Figures from Vojin MIlić suggest that in 1951/2 only around one third of university students were from peasant or manual worker families; only six years later, it had risen to $44 \%$ (Milić, 1966). By 1961/2, children of peasants had an Index of Representation of 0.33 (in a perfectly egalitarian society the Index would be 1); that of workers' children was 0.77; but for children of employees the figure was 3.3, albeit a reduction in over-representation from 4.72 in 1953/4. (ibid.)

Although the shrinking of the peasantry was complex, with many of the new industrial workers maintaining some contact with the land, there were two kinds of occupational mobility - peasants moving to manual and non-manual labour, albeit in a ratio of 2:1 to manual labour; and manual workers moving into non-manual jobs, albeit mainly into the lower echelons, with those already in non-manual jobs more or less keeping their positions. There was educational mobility in the period, although it was actually less than occupational mobility to meet the demands of industrialization and the expansion of administrative and managerial positions. Intergenerational mobility was also greater than intragenerational mobility, both in education and employment. 
In the second period, the era of self-management and consumer-led market socialism, there is a real divide between party ideologues, describing Yugoslav society in Marxist terms, and a growing body of sociologists using Durkheimian categories of social stratification (cf. Archer, Duda, Stubbs, 2014). There was very little work done on education in relation to social class, although surveys in 1976 (Previšić and Serdar, 1978) and 1987 (Rimac and Baranović, 1991) in the Socialist Republic of Croatia both point to parental levels of education as being the most important determinant of continuing to higher education. This was, also, of course, the period of the consolidation of what Djilas had termed the 'new class' (Djilas, 1957) or what the protesting students in 1968 in Belgrade termed the 'red bourgeoisie' (Klasić, 2012). It was also notable for the ambitious, but largely unsuccessful, educational reforms that came to be known as the Šuvar reforms after the sociologist, and reluctant politician, Stipe Šuvar (Bacevic, 2016). Influenced by both Bourdieu and a particular Marxist ideology, Šuvar influenced the thinking of the League of Communists of Yugoslavia as early as 1974, critiquing "a situation in which certain strata are reproducing themselves, their structures and their socio-economic positions, and with this, their social power." (quoted in Bacevic, 2016: 80). By 1977, he had not only analysed the problem but devised a solution, thus:

Education has been developed as a specific ritual which selects a small proportion of the population for the social elites, and places them on a pedestal which is inaccessible to the vast majority of the population. ... the class function of education, in our society, unlike in the societies of exploitation, is not, or should not be to help people escape the working class, but to enable them to fall back into it. (Suvar, 1977, quoted in Bacevic, 2016)

In retrospect, Šuvar's reforms were an attempt to respond to the first signs of problems in the Yugoslav economy, linked to the oil price hike in the early 1970s, and growing unemployment, including graduate unemployment, only partly offset through the safety valve of gastarbajter migration (le Normand, 2016). Politically, the demands of the Belgrade students in 1968 and the, rather different, demands of the Zagreb students in 1971, are responded to not through expansion of higher education for all, but through the intended abolition of dual gymnasium and vocational track secondary education, tying education to the supposed needs of the labour market (echoed by later STEM arguments) and, as Jana Bacevic (Bacevic, 2016) has pointed out, a pronounced anti-intellectualism. 
The third conjuncture, one of political and economic crisis, if not breakdown, led, if anything, to a reversal of earlier gains in terms of social mobility, IMF-induced austerity led to cutbacks in university places and the beginnings of a kind of informal marketization of higher education (Ružica; Kolarić and Svetlik, 1987). If we look at some statistics (Table 1), we can see how the seemingly inexorable expansion of higher education was reversed in the 1980s. At the same time, opportunities for women in higher education continued to grow, and reached over $50 \%$ by the end of socialism, albeit with marked discrepancies by subject.

\section{Table ı: Trends in Higher Education in Yugoslavia, 1938-1985}

\begin{tabular}{|ccccc}
\hline & $\begin{array}{c}\text { Higher ed } \\
\text { institutions }\end{array}$ & No. of students & $\begin{array}{c}\text { Students per 100,000 } \\
\text { pop }\end{array}$ & \% Female students \\
\hline 1938 & 26 & 16978 & & 22.6 \\
\hline 1955 & 81 & & & 28.9 \\
\hline 1960 & 204 & 140547 & 1282 & 39.4 \\
\hline 1965 & 246 & 261203 & 1850 & 39.8 \\
\hline 1970 & 294 & 394992 & 1848 & 45.4 \\
\hline 1975 & 356 & 411995 & 1515 & 45.8 \\
\hline 1980 & 300 & 350334 & 1491 & 47.4 \\
\hline 1985 & 322 & 348068 & & \\
\hline
\end{tabular}

Source: Šoljan, 1991 and Milić, 1966

Table 2: Education indicators by Yugoslav Republic 197I and 198I

\begin{tabular}{lcccc} 
& \multicolumn{2}{c}{$\begin{array}{c}\text { Average years of schooling } \\
\text { (adults 15+) }\end{array}$} & \multicolumn{2}{c}{ Illiteracy Rates (10+) \% } \\
\cline { 2 - 5 } & 1971 & 1981 & 1971 & 1981 \\
\hline Yugoslavia & 6.3 & 7.6 & 15.1 & 9.5 \\
\hline Slovenia & 8.2 & 8.9 & 1.2 & 0.8 \\
\hline Croatia & 6.7 & 7.8 & 9.0 & 5.6 \\
\hline Serbia (inc. APs) & 6.2 & 7.5 & 17.2 & 10.9 \\
\hline Bosnia - H & 5.4 & 6.9 & 23.2 & 14.5 \\
\hline
\end{tabular}

Source: Bevc (1993)

This table (Table 2) shows changes only between 1971 and 1981 but breaks down figures on average years of schooling and rate of illiteracy by Republics, in the context, of course, of the 1974 Constitutional reform. We can see that there were considerable differences between the richer and poorer Republics on both indicators, but that, unlike indices of social prod- 
uct for example, the gap narrowed, at least in the decade for which I was able to find figures.

Of course, as Suvin reminds us, any understanding of education and social mobility in socialist Yugoslavia has to address the extremely complex and rapidly changing class composition of the society and the fact that official statistics and survey data tend to obfuscate rather than clarify. In any case, the topic of social mobility was hardly central to Yugoslav sociology although some important work, primarily through large-scale international co-operation, was done in the 1980s (Sekulić, 1991). Ironically, many of the same problems arise when we look at education and social mobility in the post-socialist period.

\section{Education, mobility and the Post-Yugoslav space}

Moving on to education in the post-Yugoslav space, many of the same issues emerge, not least the problem of a lack, until relatively recently, of useful work on social class. Indeed, it is fair to say that, almost thirty years on from the moment of 'transition', we are still trapped within a 'transitology' paradigm that does not quite know how to conceptualise the societies that emerged from the ashes of Yugoslavia. I was struck, in particular, by Belgrade sociologist Ivana Spasić on the difficulty of capturing the 'chaotic' nature of post-Yugoslav societies marked by »a polarized collision between different dimensions of social stratification, which exist in parallel and struggle for (legitimate) domination, with a highly uncertain result" (Spasić, 2006). Mladen Lazić and Slobodan Cvejić (2007) have also charted contemporary Serbia, in particular, in similar terms, as a place where socialist, agrarian and capitalist market norms all co-exist leading to a period of 'manifest value confusion', described in one text as the co-existence of traditionalism, authoritarianism, nationalism and liberalism. Predrag Cvetičanin and his colleagues, albeit in a footnote, go further and argue:

In Western Balkan societies there are four major mechanisms which individuals and groups rely on in field struggles: mechanisms of social closure on the basis of belonging to party organizations and/or informal clan groupings; mechanisms of social closure on the basis of educational credentials; market mechanisms and, finally, crime. (Cvetičanin et al, 2015).

It is the concept of 'social closure' that is of most importance, I would suggest, and through an overview of some of the relevant literature, it is 


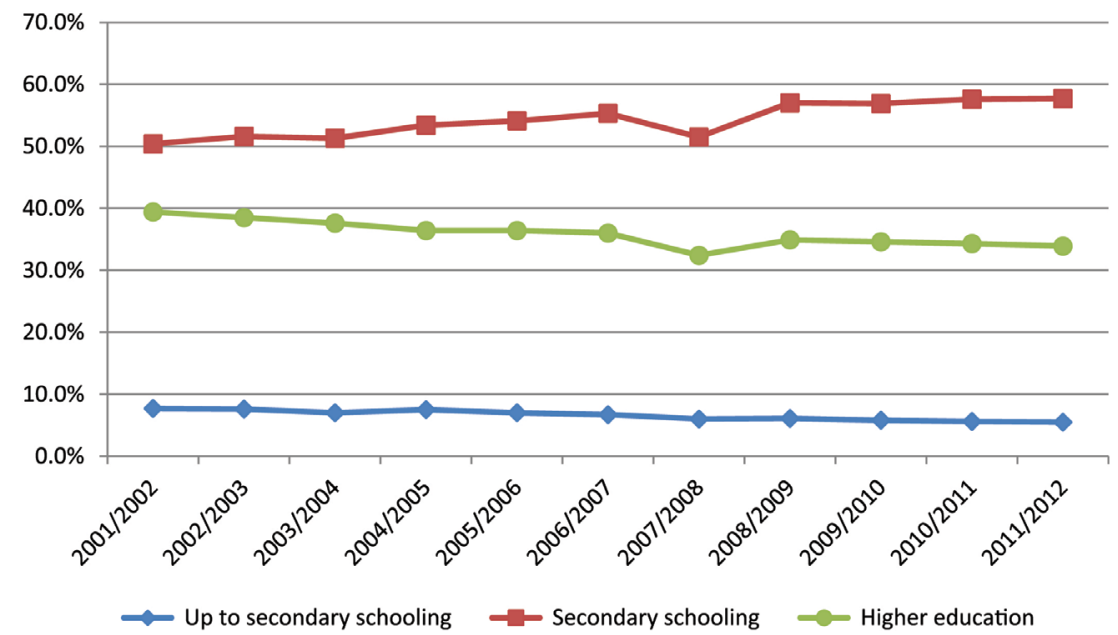

Figure i: Percentage of tertiary Level Students in Croatia By Father's Educational evel $200 \mathrm{I} / 2-20 \mathrm{II} / \mathrm{I}$

possible to trace elements of this in relation to the educational system, and particularly access to higher education. Unfortunately, there is no single text that brings together the structural and intersectional nature of educational disadvantage in our region, addressing the mutually reinforcing nature of class, gender, ethnicity, disability and region. What we have, within a normative stance that mobility is important for a kind of equal opportunity neoliberalism that leaves inequalities unchanged but allows for the exchange of elites, are crude renderings of 'educational disadvantage' by so-called 'socio-economic status' or its acronym SES (Waters and Waters, 2016). In this narrative, we are meant to prefer meritocracy to patronage, or, let us recall Katarina Kitarović here, »background, means, and connections «.

Of course, there are real problems with the deeply politicized nature of the marketization of higher education across our region: the necessity for party membership to reach positions of influence; the rise of new, and often very dubious, private universities; the number of politicians with plagiarized doctoral dissertations, and so on. However, removing all of this and leaving meritocracy intact is hardly a vision for the future. If we focus, for the moment, on Croatia, we find, even within an expansion of higher education, a reduction in the prospects of children from working-class backgrounds having access. The work of Karin Doolan and her colleagues (Doolan et al, 2017) show that student numbers rose by almost exactly $50 \%$ 

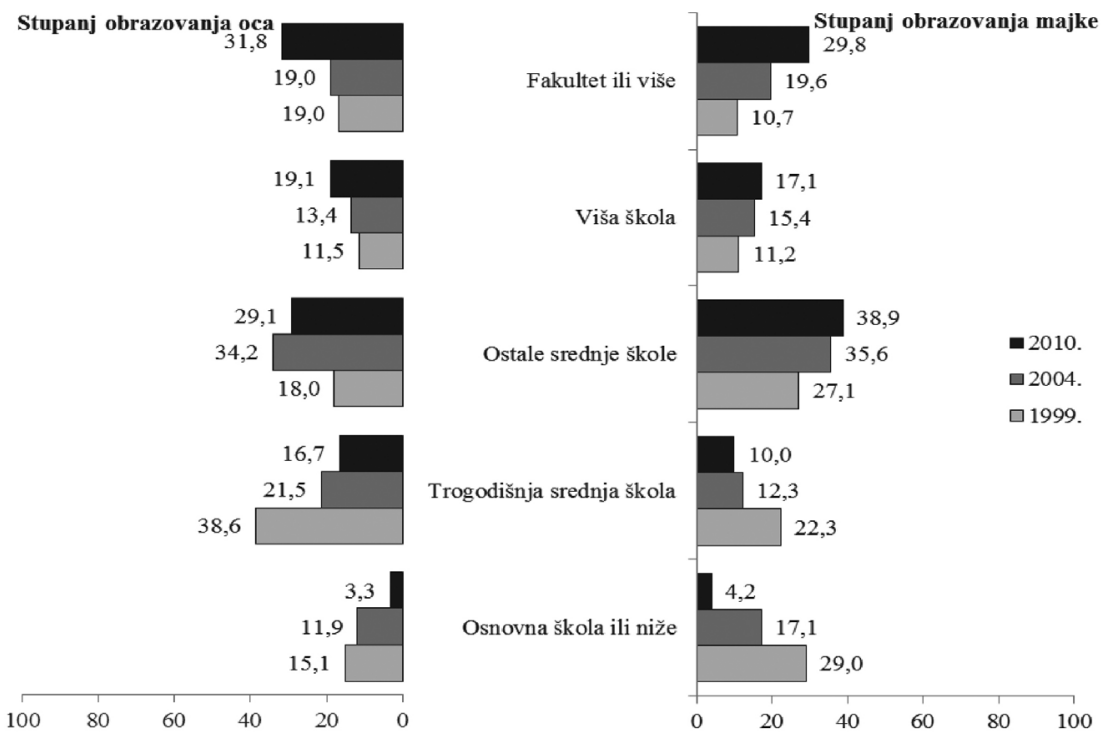

Figure 2: Levels of Education by Father and Mother's Educational Level in Croatia 19992010

Source: Ilišin (ed) (2014)

in Croatia between 2001/2 and 2013/4. As the graph shows (Figure 1), however, the share of those whose fathers did not complete secondary education, fell from an already very low base to begin with. The graph is the calculation of the authors' based on statistics they had to email the Croatian Bureau of Statistics to obtain, suggesting that information on education and mobility is still not routinely available and accessible.

Sample data from 2010 collected by Vlasta Ilšin and colleagues (Ilišin (ed), 2014) (Figure 2) show the dramatic increase in self-reproduction in university education in Croatia and its gender dimension. In 1999 only 10.7 $\%$ of university students came from families where the mother had university education, by 2010 it was $29.8 \%$. The literature also shows how the institutional structure of higher education represents a barrier to equity. The same study suggests that $80 \%$ of students received no scholarships whatsoever, and a study, again by Karin Doolan and colleagues, in 2013 (Doolan, Dolenec and Domazet, 2013), pointed out that scholarships were as much, if not more, merit-based than needs-based and that, compared to Slovenia, although living costs were approximately the same, scholarships were about half, covering less than one third of likely expenses. Crucially for me, there are no second chances: Farnell et al's study (EUROSTUDENT, 
2012) showed that only $2 \%$ of those entering higher education at university level for the first time were 21 or older. In addition, only some $5 \%$ of students reported having physical disabilities, suggesting that such students are chronically under-represented in Croatian higher education. The Doolan study hypothesizes, rather depressingly, that only when the higher education of the elite reaches saturation point, will access for working-class students improve (Doolan et al, 2013).

According to the latest EUROSTUDENT figures, $42 \%$ of students in Croatia had a least one parent who had completed tertiary education, compared to $56 \%$ for Serbia and $33 \%$ for Slovenia (EUROSTUDENT, 2018), albeit with a significant increase, of some 5 percentage points, of students in Croatia who indicated their parents did not have tertiary education compared to the previous survey. The trend in Serbia, however, is opposite, with a significant decrease of some 11 percentage points between the two surveys (ibid.).

There are very few valid and relevant cross-country comparisons including all of the post-Yugoslav states. One notable exception is a study in 2013 by Crespa Cuaresma and his colleagues (Crespo Cuaresma et al, 2013) (Figure 3). The graph below, that needs a little unpicking, shows that, between 1960 and 2010, South Eastern Europe (including all the post-Yugoslav states except Slovenia, Albania, Bulgaria, Moldova, Romania and Turkey) is the only European sub-region that shows a consistent fall in social mobility, at its greatest in the two decades from $1980-2000$. They construct an index of educational mobility which compares educational mobility, expressed as a GINI type coefficient, as the ratio of the education GINA of those aged 25-54 compared to those 55+.

Including Slovenia in the picture leads to an interesting side question about statistics. Despite its meritocratic ideology, and the unproblematic use of PISA test results, the OECD (of which Slovenia is a member, successfully blocking currently, together with Hungary, Croatia's membership) has some of the most useful and up-to-date statistics, many of which have been put together in a report from 2018 (OECD, 2018). The report suggests that some $13.5 \%$ of variation in PISA science results in Slovenia in 2015 was a result of socio-economic status, down some 4 base percentage points from 9 years earlier but above the OECD average of $12.9 \%$. The OECD defines 'disadvantaged adults' as adults with parents who did not complete lower secondary education. In 2015, only $9.5 \%$ of Slovenes from these backgrounds had completed tertiary education, although this rose to $16.5 \%$ for those aged 




Figure 3: Educational Mobility by European Region 1960-2010

Source: Crespo Cuaresma et al (2013)

26-35. The rates are lower than most of Europe with the exception of many of the post-communist states. Interestingly, although given Slovenia's small size it is hard to know how much to read into this, it had one of the highest differences in performance depending on whether disadvantaged students went to disadvantaged schools or not.

Again, there is evidence of closure; $50 \%$ of adults aged 26 or over reported that their highest level of educational attainment was the same as that of their parents, with $38 \%$ reporting doing better than their parents and 12 $\%$ worse. Interestingly, upward educational mobility was higher for those aged 46-55, who would have been 18 in the 1980s, than those aged $26-35$. The chance of Slovenes aged 26 or over completing higher education if one of their parents had also done so was 14 times greater than those where neither 


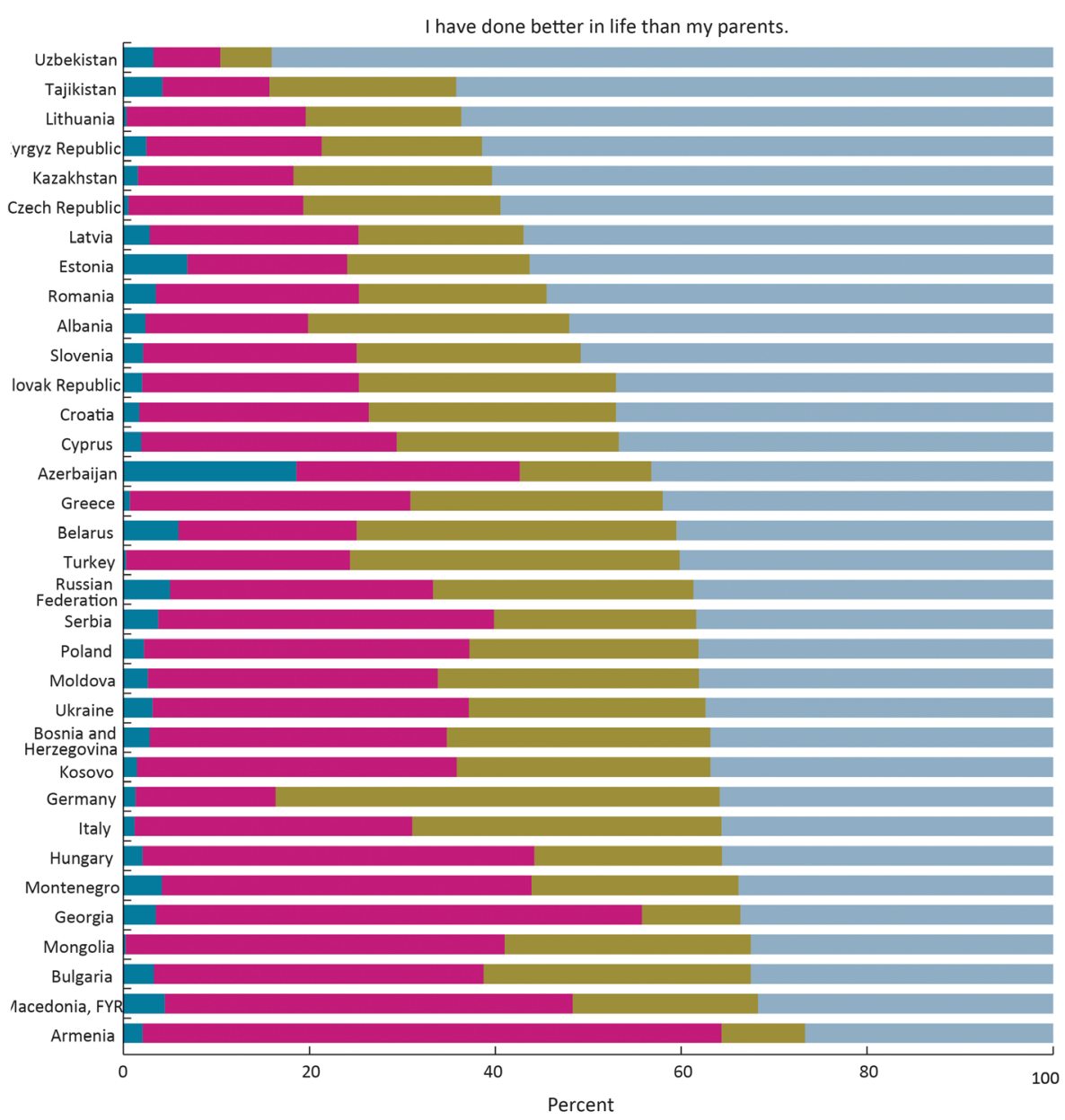

Figure 4: Question from Life in Transition Survey 2016

Source: EBRD (2016)

parent had completed upper secondary education, a ratio similar to France, and high by OECD standards, but well below figures for the Czech Republic, Slovakia or Poland, with a range between 25 and 34 times (ibid.). One similarity between Slovenia and Croatia, unsurprisingly, is that changes in class structure in the early 1990s, as Jereb and Ferjan point out for Slovenia (Jereb and Ferjan, 2008), in part at least, where as a result of the option of early retirement for manual workers whose industries had collapsed. Using 2006 survey data, they also suggest that Slovenia has higher mobility, upwards and downwards, in terms of jobs at least, than most other European countries. 
One of the most worrying aspects of access to higher education in Slovenia is a pronounced gender gap with the proportion of women aged 3034 having attained higher education exceeding that for men by some 24.1 \%. The gap amongst 25-34 years old was $23 \%$ (Eurostat, 2019). At the same time, the employment rate for tertiary educated women is below that for men, and a gender gap in earnings remains, with tertiary educated women between $25-64$ years of age earning $83 \%$ on average compared to men, although this is higher than the OECD average of $75 \%$ (ibid).

In addition, turning back to the region as a whole, a finding from the EBRD Life in Transition Survey from 2016 (EBRD, 2016) shows what might be termed subjective mobility, in terms of what percentage of adults agreed that they have done better in life that their parents. High figures for Slovenia and Croatia stand in contrast to much lower figures for Bosnia-Herzegovina, Kosovo, Montenegro and, particularly North Macedonia (Figure 4).

What the data I have shown fails to do, as well as the neglect of intersectionality, is to show the impact of quality of education, access to particular types of education, the transition from school to work, and so on. In addition, as a number of commentators stated during the "blockade" of the Faculty of Philosophy in Zagreb in 2009 when demands for free higher education were combined with a call for greater equity, educational inequality starts very early, in pre-school in fact - and is cumulative over time. By the time children reach 18 years of age, it is already too late.

\section{Poverty, coping strategies and education}

In this context, research carried out with colleagues in 2016/7 (Stubbs et al, 2017; Rubil et al, 2018), looking at the coping strategies of poor families those in receipt of social assistance, with school-age children - is highly relevant here. This was an all too rare attempt to go beyond large-scale statistical data to address the lived experiences of those living in poverty and the ways they coped with this. Hence, education was only one of many issues discussed but some observations can be made. In terms of general findings, two thirds of our interview sample reported having problems with bills and $25 \%$ had had one disconnection of a communal service, be it gas, electricity or water, in the last year. It is rare in our region, I would suggest, for social workers with clients with children who have arrears to negotiate with gas or electricity companies not to disconnect. 


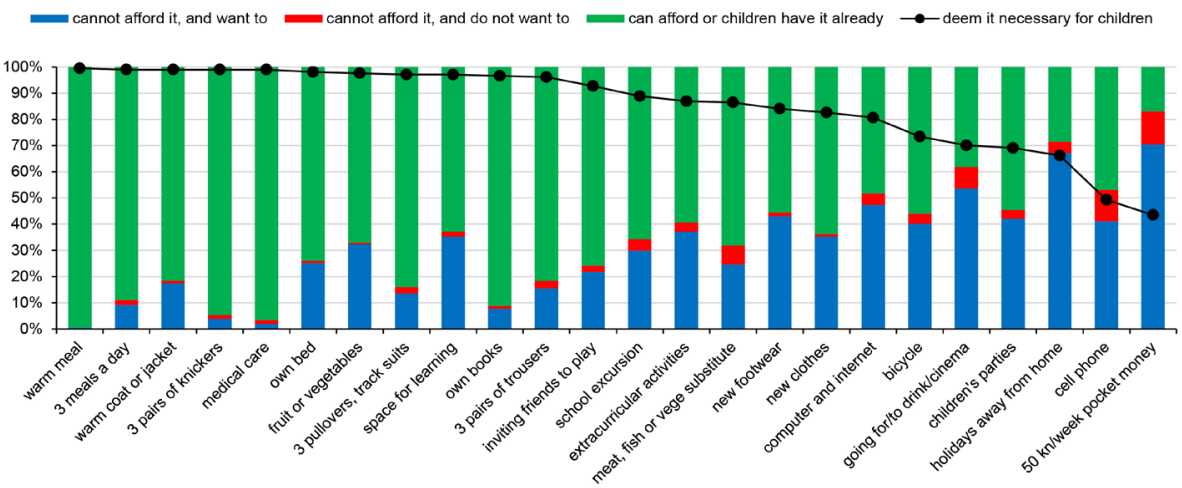

Figure 5: Parental Views on Necessities for School-Age Children

Coping strategies, all of which became less effective over time, included work in the grey economy, mostly women doing cleaning jobs or babysitting, often combined with fear of someone telling social services; selling any valuable household items; small subsistence food production, or taking food from other family members who grew their own; and borrowing on neighbours' credit cards, preferable to the high interest loan sharks who, at least in Zagreb, advertise on every street corner. After family and friends, families valued Centres for Social Work highly, with some praising the compassion of their social workers, whilst others saw them as, at best, indifferent. Interesting, given the publicity they get, NGOs, soup kitchens, church organizations and the like were much less important and those who had tried to use them found frequent changes of rules worked against them. Our work reinforced earlier studies that show how children who most need pre-school are least likely to go, with Croatia having rules that positively discriminate in favour of working parents, together with huge regional differences in rates of access (Matković and Dobrotić, 2013). One of the, perhaps, most surprising of our findings was that parents tended to have higher expectations of their children in terms of the future, levels of education, likely employment, and so on, than the children we interviewed.

The diagram shown here (Figure 5), included in the final report, points to things that parents deem necessary for children but that they cannot afford: $30 \%$ cannot afford but consider it important for children to go on a school excursion; $36 \%$ on extra-curricular activities. $80 \%$ of parents said that a computer and internet was necessary, as it certainly is, increasingly, for educational purposes, and yet almost 50\% could not afford it. Indeed, in the study, we referred to a literature on health that discusses unexpected 
significant expenditures and argued that the same concept needs to be applied to education (Ke Xu et al, 2003).

The next table (Table 3) divides the sample into those who completed only primary education and the rest. One can see that 3 in 10 children hoped to go to college or university, but that this dropped significantly if their parents had lower levels of education. For over half the children in the sample, there was a realization that lack of money might be an obstacle to fulfilling their plans (Table 4).

\section{Table 3: Educational Mobility by European Region 1960-2010}

\begin{tabular}{lccc} 
& Total sample & $\begin{array}{c}\text { Parents with Lower } \\
\text { Education }\end{array}$ & $\begin{array}{c}\text { Parents with Higher } \\
\text { Education }\end{array}$ \\
$\begin{array}{l}\text { Finish secondary } \\
\text { school and get a job }\end{array}$ & 62.6 & 67.2 & 56.8 \\
\hline $\begin{array}{l}\text { Finish a college or uni- } \\
\text { versity and get a job }\end{array}$ & 31.3 & 25.5 & 38.6 \\
\hline $\begin{array}{l}\text { Get a job as soon as } \\
\text { possible, regardless of } \\
\text { finishing school }\end{array}$ & 6.1 & 7.3 & 4.6 \\
\hline
\end{tabular}

Source: Stubbs et al (2017)

Table 4: Childrens' Preceptions of Ostacles to Fulfilling Plans

\begin{tabular}{lc} 
& TOTAL \\
\hline Lack of money & 53.5 \\
\hline Nothing & 29.3 \\
\hline Lack of real opportunities in my surroundings & 17.2 \\
\hline Lack of good information and advice & 10.1 \\
\hline Lack of correct qualifications for the job I want & 9.1 \\
\hline Family obligations & 3.0 \\
\hline Something else & 2.0 \\
\hline
\end{tabular}

Source: Stubbs et al (2017)

The focus groups with parents, all of which I conducted with a colleague, brought home the issues. This quote is from a Roma man about his daughter:

My daughter was a really good pupil and then they moved her into a different programme in the gymnasium and then she needed different books. I asked the teacher if we could exchange the books she had for the new books she needed but she didn't want to do it. And now she is failing at school because she doesn't have 
the books, she has to repeat a year and no longer has a right to a stipend. So we have enrolled her in a trade school instead.

Here are two quotes regarding the effects of peer pressure in terms of fashion and make up:

I just can't make it possible that he has the same as his friends at school. Kids are always commenting on the kinds of clothes you come to school in.

My daughter was 13 and she wanted to make herself up and she did not have trousers like the others and so they made fun of her. She came home in tears but I told her "hold your head high" and then the next month I bought her trousers. She also wants a computer but I really can't afford it. (Stubbs et al, 2017).

\section{Conclusions}

It is important to note, albeit briefly, some of the policy implications that could be derived from this paper. These are very much derived from a combination of insights from Bourdieu and the Brazilian critical educator Paulo Freire. Bourdieu, of course, has a great deal to say about educational policy, even if rarely directly (cf. Lingard et al, 2005). Taking his concept of 'field' seriously, together with 'habitus' and 'capital', points to the importance of struggles for symbolic power »in and against the state" (London-Edinburgh Weekend Return Group, 1979), and the importance of breaking down those 'logics of practice' that reproduce inequalities in education. Freire is, perhaps, more widely influential within educational policy following his landmark book Pedagogy of the Oppressed (Freire, 1970) and his subsequent work with UNESCO and others and, certainly, has a great deal to say about the nature of praxis in the 'black box' of educational policies and processes, in terms of critique of 'received' or 'banking-like' understandings of education. Even more than Bourdieu, Freire's life and work was devoted to a »liberatory pedagogy ... aimed at social transformation, at humanization, at changing the class oppression created by capitalism, and at challenging ... many other forms of oppression " (Au and Apple, 2007; 462). Combining the two re-emphasizes the importance of working at the structural and interpersonal or micro-level simultaneously to address the multifaceted reproduction of educational inequality and immobility.

In broad brush stroke terms, I outline a number of key aspects of educational policy to promote, at least, social mobility and equal opportu- 
nity whilst, of course, recognizing that these aspirations may well, themselves, fall short of the desire for a more equitable educational system for all. The first aspect is the expansion of pre-school education for all, on the grounds that this is the only possible way of ensuring a 'fair start'. At the same time, it is important that my advocacy of such a policy is not based on notions of 'parenting deficits' amongst the underprivileged that may, itself, amount to a kind of self-fulfilling prophecy, especially if the rationale for pre-school programmes is based on distorted understandings of cognitive science. Crucially, then, and secondly, the entire educational process needs to be open to greater scrutiny at grassroots level, by pupils and parents, and, at the same time, in a region where the ability to socialize in public spaces has been reduced, schools need to become genuine community resources. Thirdly, the formal and hidden curriculum needs to be more student-centred and move away from rote learning to critical consciousness ('conscientization' in Freire's terms). Fourthly, education needs to be treated as a commons, a public good open to all, and nurtured through being freely available to all. Free education is only free if there are also grants to cover living costs - and if they have to be limited, they should be based on need not so-called ability. Fifthly, meaningful participation is needed at all levels, as well as ensuring lifelong learning, second chances and, very much as the Swiss system does, multiple pathways to higher education. Children with disabilities need to be a priority, as do Roma children, not merely through scholarships for a few who can then join the middle class. More complex would be to value and support those lacking cultural capital or who do not speak in what Basil Bernstein (1971) termed 'elaborated codes' and, in this context, I would sound a warning about the current technocratic fashion for early intervention that can end up labelling the children it purports to help, instead preferring what I would term reflexive anti-oppressive practice, drawing attention to practices and structures of oppression and forming action coalitions to challenge them. In the end, perhaps, the conclusion might be that it is not possible to have a socially just educational system in a socially unjust society.

\section{Literature}

Archer, Roy, Duda, Igor and Stubbs, Paul (eds.) Social Inequalities and Discontent in Yugoslav Socialism, Abingdon: Routledge, 2016.

$\mathrm{Au}$, Wayne and M. Apple. »Reviewing Policy: Freire, Critical Education, and the Environmental Crisis«, Educational Policy, no. 21(3) (2007): 457-470. 
Bacevic, Jana. »Education, Conflict and Class Reproduction in socialist Yugoslavia." In Social Inequalities and Discontent in Yugoslav Socialism, 7794. Edited by Rory Archer, Duda, Igor and Stubbs, Paul. Abingdon: Routledge, 2016.

Bernstein, Basil. Class, Codes and Control Volume 1 Theoretical Studies Towards a Sociology of Language, London: Routledge, 1971.

Bevc, Milena. »Rates of Return to Investment in Education in Former Yugoslavia in the 1970 and 1980 o by Region«, Economics of Education Review, no. 12(4) (1993): 325-343.

Bourdieu, Pieree and Passeron, Jean-Claude. Production in Education, Society and Culture, London: Sage, 1977.

Cvjetičanin, Predrag, Misha Popovikj and Jasmina Nedeljković. »Who likes this change? Perception and evaluation of socio-economic changes in Western Balkan societies."In A Life for Tomorrow: social transformations in South-East Europe, edited by P. Cvjetičanin, I. Mangova and N. Markovikj, (S. 11-96). Skopje: Institute for Democracy, 2015.

Djilas, Milovan. The New Class: an analysis of the communist system, San Diego: Harcourt, Brace Jovanovich. 1957.

Doolan, Karin, Danijela Dolenec and Mladen Domazet, The Croatian Student Financial Support System in a European Context: a comparative study. Zagreb: Institute for the Development of Education, 2013. http://www.finhed.org/media/files/o6-ACCESS_Student_support_ENG_web.pdf

Doolan, Karin, Saša Puzić and Branislava Baranović. »Social Inequalities in Access to Higher Education in Croatia: five decades of resilient findings «, Journal of Further and Higher Education, no. 42(3) (2017): 1-15.

EBRD, Life in Transition III, Paris: EBRD, http://litsonline-ebrd.com.

Eurostudent (Cvitan, Doolan, Farnell, Matković), The Social and Economic Conditions of Student Life in Croatia. Zagreb: institute for the Development of Education, 2012. https://www.academia.edu/13099707/ Social_and_Economic_Conditions_of_Student_Life_in_Croatia_National_EUROSTUDENT_report_for_Croatia

Eurostudent (Huaschildt, Vogtle and Gwosc), Social and Economic Conditions of Student Life in Europe; EUROSTUDENT VI 2016-2018/Synopsis of indicators, Bielefled: wbv, 2018. https://www.eurostudent.eu/download_files/ documents/EUROSTUDENT_VI_Synopsis_of_Indicators.pdf

Freire, Paulo. Pedagogy of the Oppressed, New York: Continuum, 1970.

Ilišin, Vlasta. (ed.). Sociološki potret hrvayskih studenata, Zagreb: IDIZ, 2014. 
Jereb, Eva and Marko Ferjan. »Social Classes and Social Mobility in Slovenia and Europe.« Organizacija no. 41(6) (2008): 197-206.

$\mathrm{Ke} \mathrm{Xu}$ et al. »Household catarstrophic health expenditure: a multicountry analysis." The Lancet no. 9378 (2003): 111-117.

Klasić, Hrvoje. Jugoslavija i svijet 1968, Zagreb: Naklada Ljevak, 2012.

Kolarić, Zinka and Ivan Svetlik. »Jugoslovenski system blagostanja u uslovima ekonomske krize.« Sociološki pregled no. 21(1-2) (1987): 31-44.

Lazić, Mladen and Slobodan Cvejić. »Class and Values in Postsocialist Transformation in Serbia." International Journal of Sociology no. 37(3) (2007): 54-74.

Le Normand, Brigite. »The gastarbajteri as a transnational Yugoslav working class." In Social Inequalities and Discontent in Yugoslav Socialism, 38-57. Edited by R. Archer et. al. Abingdon: Routledge. 2016.

Lingard, Bob, Sandra Taylor and Shaun Rawolle. "Bourdieu and the study of educational policy: an introduction." Journal of Education Policy no. 20(6) (2005): 663-669.

London-Edinburgh Weekend Return Group, In and Against the State, London: Conference of Socialist Economists, 1979. https://ibcom.org/library/ against-state-1979

Matković, Teo and Ivana Dobrotić. »Promjene u obuhvatu programima predškolskog odgoja I obrazovanja u Hrvatskoj na nacionalnoj I županijskoj razini između 1990. I 2012. Godine."Revija za socijalnu politiku no. 20(1) (2013): 65-73.

Milić, Vojin. »General Trends in Social Mobility in Yugoslavia.« Acta Sociologica no. 9(1-2) (1966): 116-136.

OECD. Equity in Education: breaking down barriers to social mobility, Paris: OECD Publishing, 2018.

Previšić, Jozo and Vladimir Serdar. »Tko, kako I zašto na fakultet? Socijalno porijeklo I materijalni staus redovitih studenata u Hrvatskoj.« Pitanja, no. 10 (3) (1978): 4-21.

Rimac, Ivan and Branislava Baranović. »Socijalno struktura zagrebačkih studenata."In Društvenih profil zagrebačkih studenata krajem osamdesetih, 23-39. Edited by I. Magdelenić. Zagreb: Institute for Social Research, 1991.

Rubil, Ivica, Paul Stubbs and Siniša Zrinščak. »Dječje siromaštvo I strategije nošenja sa siromaštvom kućanstava u Hrvatskoj: kvantitativno-kvalitativna studija." Privredna kretanja I ekonomska politika no. 26(2) (2018): 59-116. 
Ružica, Miroslav. »Socijalna politika 8o-tih: kontinuitet ili promena strategije.« Sociološki pregled no. 21(1-2) (1987): 7-30.

Sekulić, Duško. Strukture na izmaku, klase, sukobi i socijalna mobilnost, Zagreb: Croatian Sociological Association, 1991.

Spasić, Ivana. »Distinkcija na domaći način: diskursi statusnog diferenciranja u današnjoj Srbiji.« In Nasleđe Pjera Burdijea: pouke i nedahnuća. Edited by M. Nemanjić and I. Spasić. Belgrade: Institute for Philosophy and Social Theory, 2006.

Stubbs, Paul, Marko Ledić, Ivica Rubil and Siniša Zrinščak. Child Poverty and Household Coping Strategies in Croatia, Zagreb: Institute of Economocis and Adris Foundation, 2017. https://www.eizg.hr/userdocsimages//projekti/zavrseni/Child_poverty_eng.pdf.

Stubbs, Paul. and Noemi Lendvai. »Authoritarian Neoliberalism, Radical Conservatism and Social Policy within the European Union: Croatia, Hungary and Poland." Development \& Change, no. 51(2) (2019): 540-560.

Šoljan, Nikša Nikola. »The Saga of Higher Education in Yugoslavia: beyond the myths of a self-management socialist society." Comparative Education Review no. 35(1) (1991): 131-153.

Suvin, Darko. Splendour, Misery and Possibilities: an X-Ray of socialist Yugoslavia, Leiden: Brill, 2016.

Šuvar, Stipe. Škola $i$ tvornica. Zagreb: Školska knjiga, 1977.

Waters, Tony and Dagmar Waters. Are the terms "socio-economic status" and "class status" a warped form of reasoning for Max Weber?. Palgrave Communications, 2, 2016. https://www.nature.com/articles/palcomms20162. pdf.

Županov, Josip. Od komunističkog pakla do divljeg kapitalizma, Zagreb: Hrvatska sveučilišna naklada, 2002.

\section{Webpages}

Benačić, Ana. »Grabar Kitarović o jogurtu, kruhu, zabrani izjašnjavanja »Hrvat/ic/om« I migrantima." https:/faktograf.hr/2018/og/12/grabar-kitarovic-o-jogurtu-kruhu-zabrani-izjasnjavanja-hrvat-ic-om-i-migranti$\mathrm{ma} /$ (12. 8. 2018).

Crespo Cuaresma, Jesus, K. C. Samir and Sauer, Petra. "Age-specific education inequality, education mobility and income growth." wwwforeurope Working Paper 6, web: https://epub.wu.ac.at/4716/1/WWWforEurope WPS_nooo6_MS15.pdf(1.5.2013). 
Dauenhauer, Nenad. »Bi li Kolindina kći upala na Harvard da joj majka nije bogata predsjednica?«, Index.hr, 21 May, https:/www.index.hr/vijesti/clanak/bi-li-kolindina-kci-upala-na-harvard-da-joj-majka-nije-bogata-predsjednica/2087282.aspx (1. 5. 2019).

Dnevno. »Predsjednička dinastija: nećete vjerovati kamo Kolindina kći odlazi studirati.« dnevno.hr 20 May, https://www.dnevno.hr/vijesti/predsjednicka-dinastija-necete-vjerovati-kamo-kolindina-kci-odlazi-studirati-1313157/. (1. 5. 2019).

Eurostat. „Gender Statistics«, https://ec.europa.eu/eurostat/statistics-explained/index.php/Gender_statistics\#Education (1. 5. 2019).

N1 Info. 2019. »Imovina predsjedničkih kandidata: Predsjednica štedi, Škoro najbogatiji.« http://hr.niinfo.com/Vijesti/a426609/Imovina-predsjednickih-kandidata-Predsjednica-stedi-Skoro-najbogatiji.html (20. 5. 2019).

Plivelić, Petra. »Razgovarali smo sa Zagrepčankom koja Hrvate upisuje na Harvard.« https://www.jutarnji.hr/life/zivotne-price/razgovarali-smo-sazagrepcankom-koja-hrvate-upisuje-na-harvard-nisam-se-rodila-sa-srebrnom-zlicom-ali-sve-se-moze-kad-se-hoce-ja-sam-zivi-dokaz/8891186/ (20. 5. 2019).

Trstenjak, Karla. »U Hrvatskoj se traži ogroman broj činjenica, a na Oxfordu da kažete svoje mišljenje i argumentirate ga ...«, Dnevnik.hr, https:// dnevnik.hr/vijesti/hrvatska/kci-predsjednice-kolinde-grabar-kitarovic-odlazi-studirati-na-harvard---561608.html, (21. 5. 2019).

Vojković, Goran. »Ne, frustrirani jadnici, Kolinina kći nije samo tako upisala Harvard «Index.hr, https://www.index.hr/vijesti/clanak/ne-frustrirani-jadnici-kolindina-kci-nije-samo-tako-upisala-harvard/2086998.aspx, (20. 5. 2019). 